\title{
Konseling Rasional Emotif Perilaku untuk Meningkatkan Penerimaan Diri pada Remaja Hamil Diluar Pernikahan
}

\author{
Fanny Septiany Rahayu \\ Program Studi PGSD, Fakultas Keguruan dan Ilmu Pendidikan, \\ Universitas Muhammadiyah Cirebon \\ fanny.septiany@umc.ac.id
}

\begin{abstract}
Abstrak
Persoalan yang terjadi pada remaja saat ini semakin kompleks dan perlu adanya penanganan segera dari berbagai pihak, salah satu persoalan remaja yang terjadi adalah kehamilan di luar pernikahan. Kehamilan di luar pernikahan memuat persoalan yang sangat rumit bagi remaja, terutama bagi mereka yang terlibat langsung di dalamnya. Oleh karena itu merupakan masalah yang sangat menarik. Kehamilan di luar pernikahan merupakan salah satu dampak dari perilaku seks bebas yang melanda remaja dan akhir-akhir ini yang cenderung meningkat. Remaja yang melakukan hubungan seksual pranikah sehingga mengakibatkan kehamilan di luar nikah disebabkan karena rendahnya harga diri, rendahnya pengetahuan tentang seksualitas dan, pengaruh norma kelompok sebaya yang dianutnya, status hubungan, serta rendahnya keterampilan interpersonal khususnya perempuan untuk bersikap asertif yakni sikap tegas untuk mengatakan tidak terhadap ajakan melakukan hubungan seks dari teman kencannya. Dalam membantu remaja yang memiliki kemampuan penerimaan diri rendah akibat adanya kehamilan yang terjadi diluar pernikahan, diperlukan adanya peran konseling. Peran konseling sangat penting, terutama dalam membantu individu mencapai proses perkembangan yang optimal. Seorang konselor menggunakan salah satu alternatif konseling yang dapat dilakukan yaitu konseling Rational-Emotif-Behavioral Therapy (REBT).
\end{abstract}

Kata Kunci: Konseling Rasional Emotif Perilaku; Penerimaan Diri; Remaja.

\section{PENDAHULUAN}

Kehamilan remaja di luar pernikahan memuat persoalan yang sangat rumit dan kompleks bagi remaja, terutama bagi mereka yang terlibat langsung di dalamnya. Oleh karena itu merupakan masalah yang sangat menarik. Kehamilan di luar pernikahan merupakan salah satu dampak dari perilaku seks bebas yang melanda remaja dan akhirakhir ini yang cenderung meningkat. Penduduk remaja (10-24 tahun) perlu mendapat perhatian serius karena remaja termasuk dalam usia sekolah dan usia kerja, mereka sangat berisiko terhadap masalah-masalah kesehatan reproduksi yaitu perilaku seksual pranikah. Hal ini akhirnya membuka peluang lebih besar terhadap hubungan seks pranikah dengan segala dampak yang muncul seperti kehamilan di luar nikah, kawin muda, anak-anak lahir 
diluar pernikahan, aborsi, penyakit menular seksual, depresi pada wanita yang terlanjur berhubungan seks dan lain sebagainya. Menurut data hasil survey KPAI pada 12 kota di Indonesia yang melibatkan 2.800 responden pelajar laki-laki dan perempuan, bahwa $76 \%$ responden perempuan mengaku pernah pacaran dan mengaku 6,3\% pernah melakukan hubungan seks. Sementara responden laki-laki 72 persen mengaku pernah pacaran dan sebanyak 10\% pernah melakukan hubungan seks. (KPAI, 2010). Berdasarkan baseline survey didapatkan bahwa jumlah persalinan pada remaja mencapai $11 \%$, kehamilan tidak diinginkan (Baseline Survey, 2007).

Remaja yang melakukan hubungan seksual pranikah sehingga mengakibatkan kehamilan di luar nikah disebabkan karena rendahnya harga diri, rendahnya pengetahuan tentang seksualitas dan, pengaruh norma kelompok sebaya yang dianutnya, status hubungan, serta rendahnya keterampilan interpersonal khususnya perempuan untuk bersikap asertif yakni sikap tegas untuk mengatakan tidak terhadap ajakan melakukan hubungan seks dari teman kencannya. Hal ini didukung dengan penelitian yang dilakukan oleh Brown \& Barbosa (dalam Domenico \& Jones, 2007, hlm. 4) bahwa remaja memilih kehamilan sebagai jalan alternatif dikarenakan prestasi sekolah yang memburuk, tidak memiliki harapan yang realistis tentang pendidikan atau pekerjaan sehingga hal ini dipandang sebagai langkah alternatif untuk kemandirian ekonomi dan memperoleh status dewasa.

Remaja dalam pergaulan sosialnya dihadapkan pada pembentukan identitas yang erat kaitannya dengan bagaimana remaja menilai dirinya sendiri atau mengevaluasi dirinya. Dalam pembentukan identitad diri remaja yang memperoleh keberhasilan secara sukses, maka dapat dipastikan bahwa remaja tersebut dapat memnuhi kebutuhannya. Sepeerti yang diungkapkan oleh Glasser (dalam Palmer, 2011, hlm. 529), bahwa kebutuhan kita akan cinta dan kepemilikan, akan kepedulian dan relasi dan keterhubungan dengan orang lain merupakan kebutuhan yang jauh menonjol dan mencakup bahwa semua problem jangka panjang manusia pada intinya adalah problem relasi. Artinya bahwa, Glasser lebih menekankan pada hubungan kita dengan orang lain dan menitikberatkan bahwa kebutuhan ini adalah yang paling penting.

Remaja yang memandang diri sebagai individu tidak berpenampilan menarik, merasa memiliki banyak sekali kekurangan dan merasa diri paling tidak beruntung dikarenakan kondisi kehamilan diluar pernikahan yang dialaminya akan menimbulkan penyesalan terhadap diri dan menjadi tidak percaya diri. Hal ini dapat mengakibatkan pribadi individu menjadi tertutup sehingga perkembangan kepribadian menjadi tidak sehat.

Salah satu permasalahan yang dialami remaja yang hamil diluar pernikahan adalah mengenai penerimaan mereka yang negatif terhadap diri sendiri baik secara fisik yang berubah karena kehamilan maupun goncangan psikisnya. Penerimaan negatif tersebut berdampak tidak baik terhadap perkembangan pribadi, dan aktualisasi potensi remaja. Powell (Purwanto: 2011: hlm. 27) mengungkapkan bahwa penerimaan diri yang rendah dapat dikatakan sebagai akar penyebab mengapa seseorang tidak dapat berprestasi secara 
maksimal, kurang berani, dan tidak percaya diri untuk bersaing dengan orang lain, serta ragu dalam mengambil keputusan.

Dalam membantu remaja yang memiliki kemampuan penerimaan diri rendah akibat adanya kehamilan yang terjadi diluar pernikahan, diperlukan adanya peran konseling. Peran konseling sangat penting, terutama dalam membantu individu mencapai proses perkembangan yang optimal. Penanganan konselor untuk membantu remaja yang selanjutnya disebut konseli dalam mengembangkan nilai-nilai positifnya dan kembali menjalani kehidupannya terutama kaitannya remaja yang tengah berhadapan dengan masalah yang terjadi dalam hidupnya.

Seorang konselor menggunakan salah satu alternatif konseling yang dapat dilakukan yaitu konseling Rational-Emotif-Behavioral Therapy (REBT). Darminto (2007) menjelaskan REP dikembangkan pertama kali oleh Albert Ellis pada tahun 1950-an. Ellis (Darminto, 2007) menjelaskan REP menekankan pada aspek kognisi dan emosi. Menurut Ellis \& Harper (Huchinson \& Chapman, 2005) REP juga mengajari individu tentang bagaimana menghilangkan keyakinan irasional dan menggantinya dengan keyakinan rasional untuk mengubah perasaan dan perilaku individu menjadi lebih baik dan lebih fungsional. Lebih lanjut Ellis mempercayai manusia memiliki kesanggupan untuk berpikir, dan manusia mampu melatih dirinya sendiri untuk mengubah atau menghapus keyakinankeyakinan yang menyabotase diri sendiri. Selain itu, REP sangat mungkin untuk diadaptasikan dengan berbagai macam konseli dan masalahnya.

\section{PEMBAHASAN}

\section{Pengertian Penerimaan Diri}

Allport (Hjelle \& Ziegler, 1992: hlm. 275) penerimaan diri merupakan saah satu dari enam bagian positif kesehatan mental ataupun kematangan diri. Penerimaan diri adalah toleransi atas peristiwa-peristiwa yang membuat frustasi atau menyakitkan sejalan dengan menyadari kekuatan-kekuatan pribadinya. Toleransi yang diartikan sebagai sikap membiarkan kegagalan sehingga tidak merasa tertekan dan tidak mengingat-ingat peristiwa hidup yang tidak mengenakkan dan yang dapat mengganggu kehidupan di masa datang. Penerimaan diri juga merupakan sikap yang positif, yaitu keadaan individu menerima diri sebagai seorang manusia sehingga dapat mengatasi keadaan emosionalnya (depresi, marah, takut, cemas, dan lain-lain) tanpa mengganggu orang lain.

Jersild (Hurlock, 1993: hlm. 429) secara jelas memaparkan bahwa seseorang yang menerima dirinya sendiri adalah seseorang yang menghormati dirinya serta hidup nyaman dengan keadaan dirinya, dia mampu mengenali harapan, keinginan, rasa takut, serta permusuhan-permusuhannya dan menerima kecenderungan-kecenderungan emosinya bukan dalam arti puas dengan diri sendiri tetapi memiliki kebebasan untuk menyadari sifat dari perasaan-perasaan.

Burn (1993: hlm. 294) menyatakan penerimaan diri sebagai tidak adanya sikap sinis terhadap diri sendiri dan dihubung-hubungkan dengan sikap penerimaan orang lain. Hal ini mengindikasikan bahwa orang yang menerima dirinya sendiri memandang dunia ini 
sebagai sebuah tempat yang lebih menyenangkan dibandingkan dengan orang yang menolak dirinya sendiri dan kurang defensif terhadap orang-orang lain dan mengenal dirinya sendiri dikarenakan sikapnya. Chaplin (2004: hlm. 92) memaparkan bahwa penerimaan diri (self acceptance) adalah sikap yang pada dasarnya merasa puas dengan diri sendiri, kualitas-kualitas, dan bakat-bakat sendiri, serta pengakuan akan keterbatasanketerbatasan sendiri.

Berdasarkan pendapat tokoh-tokoh tentang penerimaan diri. Maka dapat disimpulkan bahwa penerimaan diri adalah sikap positif menerima dirinya sendiri baik kelemahan maupun kelebihannya, juga sikap positif terhadap masa lalunya yang mencakup segala keberhasilan maupun kegagalan, rasa percaya diri, kematangan pribadi, dan kemanan emosional, sehingga dapat bertoleransi terhadap peristiwa-peristiwa yang menyakitkan.

\section{Proses Penerimaan Diri}

Evans (Hurlock, 1993: hlm. 453) menggambarkan penerimaan diri melalui pemahaman dan proses mencakup:

1. Kesadaran Diri (Self-Awareness)

Kesehatan mental yang lebih baik membutuhkan kesadaran dan pemahaman diri serta apresiasi dari kebutuhan dasar yang menggarisbawahi dan memotivasi tingkah laku individu.

2. Realisasi diri (self-realization)

Individu merasa puas akan apa yang telah dilakukan dan dicapai sesuai dengan kemampuannya, mencerminkan individu yang mau menerima kedaan dirinya dan keterbatasannya. Realisasi diri merupakan proses pengembangan diri dalam membentuk faktor penerimaan diri bagi individu.

\section{Aspek Penerimaan Diri}

Sheerer (Croanbach, 1963: hlm. 562), menjelaskan mengenai aspek penerimaan diri, yaitu:

1. Perasaan sederajat. Individu menganggap dirinya berharga sebagai manusia yang sederajat dengan orang lain, sehingga individu tidak merasa sebagai orang yang istimewa atau menyimpang dari orang lain. Indvidu merasa dirinya mempunyai kelemahan dan kelebihan seperti halnya orang lain.

2. Percaya akan kemampuan diri. Individu yang mempunyai kemampuan untuk menghadapi kehidupan. Hal ini tampak dari sikap individu yang percaya diri, lebih suka mengembangkan sikap baiknya dan mengeliminasi keburukannya, daripada ingin menjadi orang lain, individu akan puas menjadi diri sendiri.

3. Bertanggungjawab. Individu berani memikul tanggungjawab atas perilaku yang dimilikinya. Sifat ini tampak dari perilaku individu yang menerima kritik dan menjadikannya sebagai suatu msukan yang berharga untuk mengembangkan diri. 
4. Orientasi keluar diri. Individu lebih mempunyai orientasi diri keluar daripada kedalam diri, tidak malu yang menyebabkan individu lebih suka memperhatikan dan toleran terhadap orang lain, sehingga akan mendapatkan penerimaan sosial dari lingkungan.

5. Berpendirian. Individu lebih suka mengikuti standarnya sendiri daripada mengikuti tekanan sosial. Individu yang mempunyai sikap dan kepercayaan diri atas tindakan yang diperbuatnya daripada mengikuti standar dari orang lain serta mempunyai ide, aspirasi, dan pengharapan diri.

6. Menyadari keterbatasan. Individu tidak menyalahkan diri akan keterbatasannya dan mengingkari kelebihannya. Individu cenderung mempunyai penilaian yang realistik tentang kelebihan dan kekurangannya.

7. Menerima sifat kemanusiaan. Individu tidak menyangkal atas emosi yang dimilikinya dan tidak merasa bersalah secara berlebihan. Individu mengenali perasaan marah, takut, atau, cemas tanpa menganggapnya sebagai suatu yang harus diingkari atau ditutupi.

\section{Landasan Teori Konseling Rasional Emotif Perilaku}

Konseling REP yang dijelaskan oleh Ellis (Corey, 2009) merupakan model konseling yang mengajarkan konseli untuk mengarahkan atau menerapkan keyakinan atau pikiran pribadi yang rasional dengan mengubah pikiran yang irrasional dengan menggunakan prinsip-prinsip REBT. Dalam mengidentifikasi permasalahan-permasalahan yang dialami individu, Ellis mengemukakan teori kepribadian yang dikenal dengan teori A-B-C. Corey (2009) menjelaskan teori A-B-C seperti berikut, A (Activating Event) merupakan keberadaan suatu fakta, peristiwa, tingkah laku, atu sikap seseorang, B (Belief) merupakan keyakinan individu tentang A yang menjadi penyebab $\mathrm{C}$, dan $\mathrm{C}$ (Consequence) merupakan konsekuensi atau reaksi emosional seseorang yang layak maupun tidak layak. Seorang terapis harus melawan D (Disputing Intervention) keyakinan-keyakinan irasional itu agar individu dapat menikmati dampak-dampak E (Effective New Philosophy) psikologis positif dari keyakinan-keyakinan rasional sehingga menemukan perasaan baru yang digambarkan dengan $\mathrm{F}$ (New Feeling).

\section{Tujuan Konseling Rasional Emotif Perilaku}

Tujuan standar dalam konseling REP adalah membantu konseli untuk mengidentifikasikan masalah emosi dan perilaku serta mengatasi masalah-masalah tersebut. Sementara itu tujuan yang lebih ideal (yang belum dapat dicapai oleh seluruh konseli) adalah membantu konseli membuat perubahan filosofis yang mendasar diantaranya: menyerah untuk menuntut diri sendiri, orang lain, dan dunia; berhenti memberi peringkat secara ekstrim terhadap diri sendiri, orang lain, dan dunia; menerima diri sendiri dan orang lain sebagai manusia yang tidak lepas dari kesalahan; menerima dunia atau lingkungan sebagai suatu sistem kompleks; dan mampu mentoleransi ketidaknyamanan (Dyden \& Neenan, 2004). 


\section{Proses Konseling Rasional Emotif Perilaku}

Proses konseling REP terdiri dari tiga tahapan utama dan dalam setiap tahapan konselor dapat menggunakan berbagai teknik yang disesuaikan dengn permasalahan dan karakteristik konseli. Ketiga tahapan utama dalam konseling REP dijelaskan oleh Dryden \& Neenan (2004) sebagai berikut.

1. Tahap Awal (Beginning Stage)

a. Membangun aliansi kerja

Tugas pertama dari konselor REP adalah memulai sesi pertama konseling dengan memberi salam kepada konseli dan mulai membangun aliansi terapeutik yang produktif dengan konseli melalui diskusi mengenai alasan konseli mengikuti konseling, menjelaskan tujuan konseling, dan membantu menjelaskan miskonsepsi tentang konseling.

b. Mengajarkan model ABC

Tugas lain yang harus dilakukan diawal kegiatan konseling adalah mengajarkan model gangguan emosional pada konseli. Pertama, konselor membantu konseli untuk memahami permasalahan emosionalnya. Kedua, konselor membantu konseli untuk memahami dalam rangka mengubah emosi disfungsionalnya dan memeriksa bagaimana keyakinan yang mereka miliki apakah rasional atau irrasional. Ketiga, konselor mendorong konseli untuk memparktikan apa yang mereka peroleh dalam sesi konseling dalam kehidupan sehari-hari.

c. Mengatasi keraguaan konseli

Konseli memiliki preferensi sendiri mengenai apa yang menurutnya berguna bagi penyelesaian masalahnya, termasuk hal-hal terkait metode konseling REP, konselor dapat memberi target waktu penggunaan metode tersebut misalnya 5 sesi pertama (Dryden \& Neenan, 2004).

2. Tahap Pertengahan (Middle Stage)

a. Mempertimbangkan untuk mengubah fokus masalah

Konseli harus memperoleh pengalaman terkait mempertanyakan keyakinan irrasional yang mempengaruhi permasalahannya serta mempertimbangkan keyakinan rasional yang menjadi alternatifnya.

b. Mengidentifikasi dan memodifikasi keyakinan irrasional inti

Penting bagi konselor untuk mencari tema utama dari keyakinan irrasional yang mengakari permasalahan konseli.

c. Mendorong konseli untuk terlibat dalam tugas-tugas yang relevan

Tujuan utama konselor selama sesi pertengahan adalah mendorong konseli untuk memperkuat pendirian terkait keyainan rasionalnya supaya dapat mencapai tujuan tersebut dan dapat menggunakan beragam teknik konseling REP.

d. Mengatasi hambatan terhadap perubahan

Konselor diharapkan dspat membantu konseli menerima perasaan "asing" tersebut yang merupakan bagian alami dari suatu perubahan dan konseli tidak harus selalu merasa nyaman dan wajar terhadap perasaan tersebut. 
e. Mendorong konseli untuk memelihara dan meningkatkan pencapaian

Konselor harus membantu konseli mengatasi hal-hal yang dapat membawa pada kemunduran, memelihara kemajuan yang telah dicapai dan meningkatkan lagi upaya untuk menginternalisasikan keyakinan irrasional dan mencapai tujuan.

f. Mendorong konseli untuk mencapai konselor bagi dirinya sendiri

Pada tahap akhir pertengahan, tugas penting konselor REP adalah memotivasi konseli untuk menjadi konselor bagi dirinya sendiri dengan mengajak konseli berdiskusi mengenai masalah yang dihadapi.

3. Tahap akhir (Ending Stage)

Pada tahap akhir, dimulai ketika konseli dianggp telah membuat kemajuan signifikan menuju peneyelesaian masalah utama denngan menggunakan pemecahan masalah REP. Selama tahap akhir, konselor dapat mendorong konseli untuk mengantisipasi masalah yang mungkin terjadi di masa mendatang dengan menggunakan keterampilan-keterampilan yang diperoleh dari proses konseling REP yang telah dilaksanakan. Konseli diharapkan dapat memandang dirnya sebagai sumber utama pemecahan masalah.

\section{Penerimaan Diri pada Remaja Hamil Diluar Pernikahan}

Masa remaja merupakan periode transisi perkembangan antara masa kanak-kanak dengan masa dewasa yang melibatkan perubahan-perubahan biologis, kognitif, dan sosioemosional (Santrock, 2007, hlm. 20). Selain itu, menurut Erikson, remaja berada dalam tahap identity versus identity confusion. Pada tahap ini remaja mulai merasakan suatu perasaan tentang identitas diri sendiri dan perasaan bahwa ia adalah individu yang unik yang siap memasuki suatu peran yang berarti di tengah masyarakat, baik peran yang bersifat menyesuaikan diri maupun yang bersifat memperbaiki diri (Hurlock, 1980, hlm. 239). Berbagai macam persoalan terjadi pada masa remaja salah satunya adalah kehamilan remaja diluar pernikahan.

Kehamilan remaja diluar pernikahan termasuk dalam kenakalan remaja dan dapat dikategorikan sebagai perilaku menyimpang dan dapat dianggap sebagai sumber masalah. Perilaku menyimpang terjadi karena kurangnya kesadaran remaja akan kehidupan mereka. Terbatasnya perhatian orang tua, pendidikan agama, pengetahuan tentang norma serta tidak terbatasnya pergaulan remaja dengan teman sebayanya.

Penelitian Eddy (2009) menjelaskan, pernikahan dan kehamilan di usia dini menunjukkan dampak negatif sosial jangka panjang. Hal ini terjadi karena remaja mengandung di usia dini akan mengalami trauma berkepanjangan, selian itu juga mengalami krisis percaya diri. Remaja juga secara psikologis belum siap untuk menerima keadaan dirinya yang berubah baik secara fisik dan komentar dari orang-orang sekitar. Sehingga jelas bahwa kehamilan remaja diluar pernikahan menyebabkan imbas negatif dan guncangan psikis untuk dirinya.

Individu yang menerima dirinya akan menyadari segala kemampuan yang dimilikinya dan dapat memanfaatkannya semaksimal mungkin, serta menyadari segala 
kekurangannya tanpa menyalahkan dirinya sendiri akan keterbatasan yang dimilikinya. Penerimaan diri sendiri merupakan keputusan sadar yang dibuat individu ketika mereka mengambil tanggung jawab atas kehidupan mereka dan menyadari bahwa mereka berada pada kontrol keputusan yang menciptakan dunia pribadi mereka serta ketika mereka melihat dunia dan diri mereka sendiri dengan penuh kesadaran maka mereka dapat menerimanya tanpa syarat (Carson \& Langer, 2006, hlm. 42).

Penerimaan diri mengungkap suatu tingkatan kesadaran individu tentang karakteristik pribadinya dan adanya kemauan untuk hidup dengan keadaan tersebut (Pannes dalam Hurlock, 1973). Individu dengan penerimaan diri merasa bahwa karakteristik tertentu yang dimiliki adalah bagian diri yang tidak terpisahkan, yang selanjutnya dihayati sebagai anugerah. Segala apa yang ada pada dirinya dirasakan sebagai sesuatu yang menyenangkan, sehingga individu tersebut memiliki keinginan untuk terus dapat menikmati kehidupan termasuk didalamnya adalah masa remaja.

Dalam kasus kehamilan remaja diluar pernikahan, peran konselor dalam membantu konseli sangatlah penting. Kondisi remaja yang hamil diluar pernikahan dianggap sebagai suatu "aib" oleh kebanyakan masyarakat bahkan juga oleh keluarganya sendiri karena dianggap sudah mencemarkan nama baik keluarga dengan perbuatan yang tidak seharusnya dilakukan. Penolakan yang dilakukan keluarga dan masyarakat membuat remaja akhirnya menolak dirinya dan memunculkan pemikiran-pemikiran irasional baik kepada dirinya dan calon bayi yang dikandungnya. Dalam konseling REP, konselor membantu konseli untuk menerima dirinya secara utuh dan merubah pemikiran serta perilaku yang irasional menjadi perilaku dan pemikiran yang rasional serta positif dengan teknik mempertanyakan keyakinan irasionalnya sehingga permasalahan remaja akan penolakan diri akibat hamil diluar pernikahan dapat segera diatasi. Konseling dilakukan menggunakan potensi yang dimilikinya, demi untuk kesejahteraan pribadi maupun masyarakat. Konseli juga dapat belajar memecahkan masalah yang terjadi dalam hidupnya dan menemukan kebutuhan-kebutuhan yang akan datang untuk dirinya serta orang sekitarnya.

Ellis (Dryden \& Neenan, 2004) menjelaskan dalam konseling REP, manusia merasakan kebahagiaan yang lebih ketika menentukan tujuan dan sasaran hidupnya secara aktif hingga sasaran tersebut tercapai. Sementara itu, rasional dalam lingkup teori konseling REP adalah hal-hal utama yang dapat membantu individu mencapai tujuan dan sasaran mendasarnya, sedangkan irrasional mengacu pada hal-hal yng menghambat individu dari pencapaian tujuan dan sasaran mendasarnya. Konseling REP ditujukkan untuk membantu konseli bertanggungjawab atas konstruksi yang dibuat dan dapat mengubahnya ketika konstruksi tersebut mulai tidak terlihat empiris, tidak logis, dan menyalahkan diri. 


\section{SIMPULAN}

Kehamilan remaja diluar pernikahan menjadi permasalahan yang kompleks jika tidak segera ditangani. Konselor sebagai seorang yang ahli membantu konseli menghadapi permasalahan yang terjadi sehingga konseli mampu mencapai perkembangan yang optimal. Tenik konseling rasional emotif perilaku bertujuan untuk mengubah pemikiranpemikiran irasional yang dibuat oleh remaja yang hamil diluar pernikahan untuk menjadi pemikiran yang lebih rasional dengan cara menerima keadaan yang sudah terjadi dan menerima keadaan dirinya serta didorong untuk memikirkan apa yang harus dilakukannya kedepan untuk dirinya dan calon bayi yang dikandungnya.

Konseling REP berupaya meningkatkan keinginan diri yang dimiliki remaja hamil diluar pernikahan dengan cara membantu konseli mencapai kebahagaian yang mereka inginkan. Keinginan diri yang tinggi harus dibedakan dengan egoisme yang ditandai dengan pengejaran kebahagian oleh seseorang tanpa mempedulikan tujuan dan pandangan orang lain yang artinya keinginan tinggi harus melihat juga pandangan dari sisi orang lain dan tetap memperhatikan norma yang berlaku dimasyarakat.

\section{DAFTAR PUSTAKA}

Baseline Survey [online] diakses di http://sbm.gov.in/BLS2012/Home.aspx pada tanggal 21 Desember 2015.

Burn, R. B. (1993). The Self Concept Theory, Measurement, Development, and Behavior. London and New York: Longman Group.

Carson, S.H. \& Langer. (2006). Mindfullness and Self-AcceptanceTheory, Practice, and Research. London: Springer.

Chaplin, J.P. (2004). Kamus Lengkap Psikologis(diterjemahkan oleh Kartini kartono). Jakarta: PT. Raja Grafndo Persada.

Chroanbach, I.J. (1963). Educational Psychology. New York: Harcourt, Brace, \& World, Inc.

Corey, Gerald. (2009). Teori dan Praktek Konseling dan Psikoterapi. Bandung: Rafika Aditama.

Darminto, E. (2007). Teori-teori Konseling. Surabaya: Unesa University Press.

Domenico, Desirae M. \& Karen H. Jones. (2007). Adolscent Pregnancy in America: Causes and Responses. The Journal for Vocational Special needs Education. Volume 30, Number 1, Fall.

Dryden, W., \& Neenan, M. (2004). Rational Emotive Behavioral Counselling in Action (3rd. Ed). London: SAGE Publication Ltd. 
Eddy. (2009). Pernikahan Usia Dini dan Permasalahannya. Sari Pediatri. 11 (2).

Hjelle, L.A., Ziegler, D. J. (1992). Personality and Theories Basic Assumptions, Research, and Applications. Singapore: McGraw Hill International Book Company.

Huchinson, G.T., \& Chapman,. B.P. (2005). Logotherapy - Enchancer REBT: An Integration of Discovery and Reason. Journal of Contemporary Psychotherapy, 35 (2), pp. 145-155.

Hurlock, E.B. (1973). Psikologi Perkembangan. Jakarta: Erlangga.

Hurock, E.B. (1980). Psikologi Perkembangan: Suatu Pendekatan Sepanjang Rentang Kehidupan. Jakarta: Gramedia.

Hurlock, E.B. (1993). Psikologi Perkembangan: Suatu Pendekatan Sepanjang Rentang Kehidupan (Terjemahan Isti Widayanti). Jakarta: Erlangga.

John W, Santrock. (2007). Perkembangan Anak. Jilid 1 Edisi Kesebelas. Jakarta: PT Erlangga.

KPAI (Komisi Perlindungan Anak Indonesia) [online] diakses di www.kpai.go.id pada tanggal 21 Januari 2016.

Palmer, Stephen.(2011). Konseling dan Psikoterapi. Yogyakarta: Penerbit Pustaka Belajar.

Purwanto, Yadi. (2011). Hubungan Antara Penerimaan Diri Dengan Kompetensi Interpersonal Pada Remaja. Skripsi Sarjana Psikologi FIP UPI Bandung: tidak diterbitkan. 